\title{
ANALISA CHARGING TIMESISTEM SOLAR CELL MENGGUNAKAN PENCARI ARAH SINAR MATAHARI YANG DILENGKAPI DENGAN PEMFOKUS CAHAYA
}

\author{
Achmad Shodiqin ${ }^{1,} \mathrm{a}^{*}$ ), Ahmad Yani ${ }^{2, \mathrm{~b}}$ ) \\ Jurusan Teknik Mesin Fakultas Teknik Universitas Trunajaya Bontang. (1,2 \\ Jl.Taekwondo RT.9 No. 55 Telp./Fax. (0548) 3035920 Bontang-Kaltim 75311 \\ Email: achmadshodiqin96@yahoo.co.id ${ }^{\text {a) }}$,yanibima@gmail.com ${ }^{\text {b) }}$
}

\begin{abstract}
Abstrak
Solar cell yang kita kenal saat ini masih memiliki beberapa kekurangan, salah satunya adalah charging time yang singkat, oleh karena itu diperlukan sebuah sistem tambahan yang dapat meningkatkan charging time dengan harapan solar cell mendapatka cahaya matahari yang tepat tegak lurus serta di fokuskan saat diterima oleh panel surya sehingga menghasikan energi listrik yang lebih besar, pencari arah cahaya matahari yang dilengkapi dengan pemfokus cahaya berpengaruh terhadap charging time, pada solar cell yang dilengkapi dengan pencari dan pemfokus cahaya dapat meningkatkan charging time sebesar $42.8 \%$.
\end{abstract}

Kata kunci : pemfokus cahaya, pencari arah cahaya matahari, solar cell, charging time.

\section{Pendahuluan}

Matahari merupakan sumber energi yang bersih dan ramah lingkungan. Energi ini sangat cocok digunakan pada negara tropis seperti di Indonesia, karena letak geografis Indonesia yang berada di atas garis katulistiwa maka Indonesia memiliki potensi energi surya yang sangat besar. Setiap hari, di Indonesia dapat diperoleh energi sebesar 4,8-6,0 $\mathrm{kWh} / \mathrm{m} 2$ pada bidang horizontal yang tidak terlindung. Energi ini dapat dimanfaatkan secara langsung maupun segara tidak langsung. ${ }^{[1]}$

Secara langsung energi matahari dapat dimanfaatkan untuk meneringkan pakaian, hasil pertanian, maupun sebagai pemanas air. Pada pembangkit listrik tenaga matahari langsung, cahaya matahari difokuskan ke sebuah menara untuk memanaskan cairan didalamnya yang akan digunakan untuk memutarkan turbin.

Pemanfaatan energi listrik yang berasal dari matahari juga dapat dilakukan menggunakan efek photovoltaic, efek photovoltaic ini digunakan dalam sebuah solar cell yang terdiri dari susunan semiconductors untuk menghasilkan energi listrik.

Namun sayangnya solar cell yang kita gunakan masih memiliki daya yang kecil dibandingkan dengan biaya pembelian yang relative mahal, apalagi jika solar cell tersebut menggunakan sudut pemasangan yang konstan (tetap).

Untuk memaksimalkan dari system charging maka diperlukan sebuah sistem tambahan yang dapat membuat solar cell menghasilakan tegangan atau voltase maupun arus listrik yang maksimal agar menghasilkan charging time yang paling lama (maksimal). charging time yang dimaksud pada penelitian ini adalah disaat solar cell menghasilkan daya melewati spesifikasi baterai yang digunakan ${ }^{[11]}$

Penelitian ini dilakukan untuk mengetahui peningkatan charging time pada panel solar cell yang telah dilengkapi dengan pencari arah cahaya matahari dan pemfokus cahaya.

\section{Tinjauan Pustaka}

\section{Pengertian Solar cells (Photovoltaic)}

Menurut bahasa, kata Photovoltaic berasal dari bahasa Yunani photos yang berarti cahaya dan volta yang merupakan 
nama ahli fisika dari Italia yang menemukan tegangan listrik. Secara sederhana dapat diartikan sebagai listrik dari cahaya. Photovoltaic merupakan sebuah proses untuk mengubah energi cahaya menjadi energi listrik. ${ }^{[7]}$ Proses ini bisa dikatakan kebalikan dari penciptaan laser.

Solar cells atau panel surya adalah alat untuk mengkonversi tenaga matahari menjadi energi listrik. Photovoltaic adalah teknologi yang berfungsi untuk mengubah atau mengkonversi radiasi matahari menjadi energi listrik secara langsung. Efek photovoltaic pertama kali ditemukan oleh Henri Bacquerel pada tahun 1839, ${ }^{[12]}$ efek photovoltaic adalah sebuah fenomena dimana suatu sel photovoltaic dapat menyerap energi cahaya kemudian merubahnya menjadi energi listrik. Selain pada Solar cells, fenomena ini dapat pula kita amati disaat kita menjemur sebuah diode dan pada kedua kaki dari diode akan menghasilkan arus listrik.

\section{Prinsip kerja Solar cells (Photovoltaic)}

Energi solar atau radiasi cahaya terdiri dari biasan foton-foton yang memiliki tingkat energi yang berbeda-beda. Perbedaan tingkat energi dari foton yang menentukan panjang gelombang dari spectrum cahaya. Ketika foton mengenai suatu sel photovoltaic, maka foton tersebut dapat dibiaskan dan diserap kemudian diteruskaan menembus sel photovoltaic. ${ }^{[4]}$ Foton yang diserap oleh sel photovoltaic inilah yang akan memicu timbulnya energi listrik.

Pada siang hari modul surya/panel solar cell menerima cahaya matahari yang kemudian diubah menjadi listrik melalui proses photovoltaic. Energi listrik yang dihasilkan oleh modul surya dapat langsung disalurkan ke beban atau disimpan dalam baterai sebelum digunakan ke beban. Dan arus searah DC (direct current) yang dihasilkan dari modul surya yang telah tersimpan dalam baterai sebelum digunakan ke beban terlebih dahulu. Ilustrasi prinsip kerja solar cell sebagaimana ditunjukkan pada gambar 1. ${ }^{[6]}$
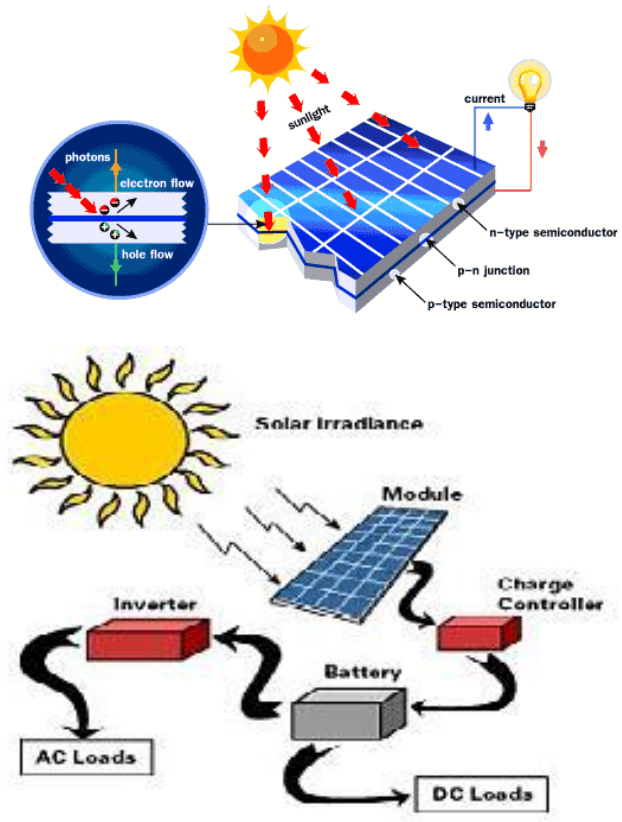

Gambar 1. Konsep kerja solar cell

\section{Karakteristik Panel Fotovoltaik}

Sifat-sifat listrik dari modul surya biasanya diwakili oleh karakteristik arus tegangannya. Jika sebuah modul surya dihubung singkat $\left(\mathrm{V}_{\text {modul }}=0\right)$, maka arus hubung singkat $\left(\mathrm{I}_{\mathrm{sc}}\right)$ mengalir. Pada keadaan rangkaian terbuka $\left(\mathrm{I}_{\text {modul }}=0\right)$, maka tegangan modul disebut tegangan terbuka $\left(\mathrm{V}_{\mathrm{oc}}\right){ }^{[5]}$

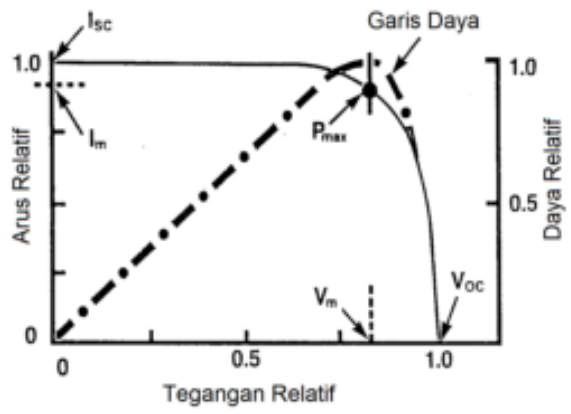

Gambar 2. Kurva Arus-Tegangan dari solar cell

Daya yang dihasilkan modul surya, adalah sama dengan hasil kali arus dan tegangan yang dihasilkan oleh modul surya. Persamaan daya sebagaimana ditunjukkan pada persamaan 1. ${ }^{[5]}$

$$
P=V x I \text {. }
$$


Dengan :

$\mathrm{P}=$ Daya keluaran modul (Watt)

$\mathrm{V}=$ Tegangan kerja modul (Volt)

$\mathrm{I}=$ Arus kerja modul (Amperee)

Apabila Solar cells digunakan sebagai sumber listrik dari baterai 12 volt, maka tegangan listrik minimal yang diperlukan untuk melakukan proses charging sebesar 12 volt dengan arus listrik yang dapat kita lakukan pengukuran menggunakan ampre meter. Jika kita memiliki Solar cells dengan daya sebesar 20 WP dan tegangan pada saat charging sebesar 12 volt maka:

$$
\begin{aligned}
& \mathrm{I}=\mathrm{P} / \mathrm{V} \ldots \ldots \ldots \ldots \ldots \\
& \mathrm{I}=20 \mathrm{WP} / 12 \text { volt } \\
& \mathrm{I}=1.67 \mathrm{ampre}
\end{aligned}
$$

Berarti Solar cells dengan daya $20 \mathrm{WP}$ (watt peak) dengan tegangan pengisian sebesar 12 volt mampu mengalirkan arus sebesar 1.67 ampre. Jika Solar cells terpapar radiasi matahari selama 5 jam berarti daya yang dihasilkan sebesar: 20 $\mathrm{WP} \times 5$ jam $=100$ wat hours.

Jika tegangan sebesar 12 volt berarti mampu mengalirkan 8.3 ampre selama 5 jam. berarti jika kita menggunakan Solar cells dengan daya sebesar $20 \mathrm{WP}$, maka minimal kita menggunakan baterai dengan spesifikasi tegangan 12 volt dengan kapasitas minimum sebesar 8.3 ah.

Setelah kita mendapat nilai daya maka kita dapat mencari presentase penambahan atau pengurangan dengan rumus :

$$
(\mathrm{X}: \mathrm{Y}) \times 100=\%
$$

$\mathrm{X}=$ selisih dari kedu buah nilai

$\mathrm{Y}=$ nilai dari data yang akan dicari presentasenya

Contoh : Sebuah solar cell menghasilkan daya 12 watt dan saat menggunakan pemfokus cahaya daya yang dihasilkan adalah 18 watt maka presentase nya adalah.

$(18-12=6)$

$$
(6: 12) \times 100=0,5 \times 100=50 \%
$$

Sedangkan charging time adalah waktu dimana sebuah solar cell melakukan proses pengisian pada alat penyimpan energi listrik berupa batterai dengan syarat tegangan dari solar cell telah melampaui tegangan batterai.

\section{Metodologi Penelitian}

Penelitian ini dilakukan di lingkungan Universitas Trunajaya Bontang. Dan waktu pengumpulan data berlangsung selama satu bulan dari pada tanggal 1 Desember 2015 sampai dengan 30 Januari 2016 dan waktu pengambilan data setiap hari cerah dari jam 07.00 hingga 17.00 WITA.

\section{Variabel Penelitian}

Ada dua jenis variabel yang digunakan dalam penelitian ini yaitu variabel bebas dan variabel terikat.

1. Variabel bebas

variabel bebas adalah variabel yang bebas ditentukan nilainya sebelum dilakukan penelitian. variabel bebas yang ditetapkan oleh peneliti adalah watu pengambilan data dari solar cell dengan tegangan kerja 5 volt 300 mili ampre yang akan diambil tiap satu jam.

2. Variable terikat

variabel terikat adalah variabel yang nilainya sangat tergantung pada variabel bebas dan merupakan hasil dari penelitian variabel bebas yang diamati peneliti adalah charging time pada solar cell ( charging time yang dimaksud adalah disaat solar cell menghasilkan daya melewati spesifikasi baterai yang digunakan).

\section{Bahan dan Alat Penelitian}

Pada penelitian kali ini digunakan dua buah solar cell polycristaline dengan bentuk bulat yang memiliki ukuran diameter frame 70 milimeter dan panjang cell 50 milimeter dan lebar 48 milimeter dengan spesifikasi tegangan kerja 5 volt dan sebuah lensa cembung spesifikasi diameter 140 milimeter dengan fokus 100 milimeter serta sebuah motor DC (direct current). 


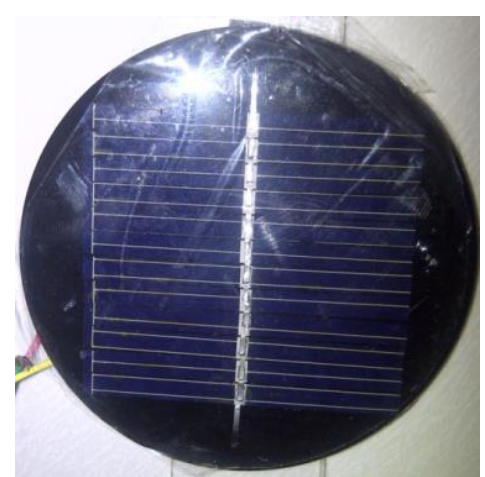

Gambar 3. Solar cell

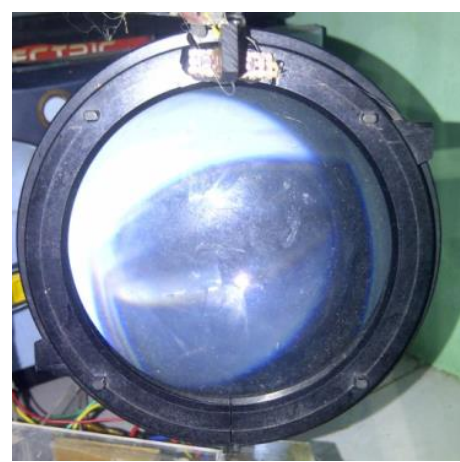

Gambar 4. Lensa cembung

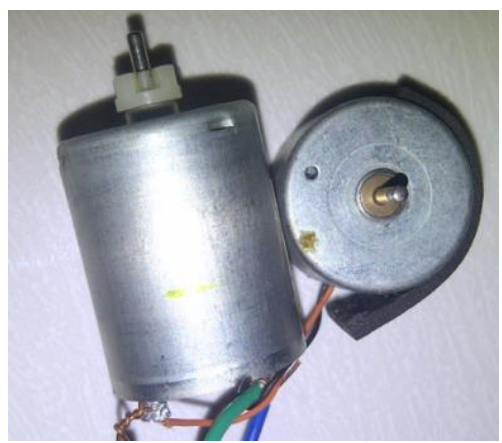

Gambar 5. Motor DC

Controller Pencari Arah Matahari. Controller tersebut berisikan komponen sebagai berikut:

a. IC op-amp LM324 berfungsi sebagai komparator yang akan membandingkan input pada kaki A dan B, kika kaki A lebih atau sama dengan kaki B maka IC akan mengeluarkan arus suplay 5 volt pada kaki output.

b. LDR (Light Dependent Resistor) berfungsi sebagai sensor cahaya yang akan memiliki hambatan yang berbeda terhadap intensitas cahaya yang jatuh diatasnya. c. Transistor berfungsi sebagai switch yang akan bekerja mengalirkan arus listrik dari emitter ke collector jika base mendapatkan ground.

d. Dioda berfungsi sebagai cek valve yang akan mengalirkan arus listrik hanya dari anoda ke katoda.

e. Kapasitor disini difungsikan sebagai penstabil tegangan listrik yang masuk ke dalam sistem agar mengurangi fluks.

f. Resistor berfungsi memberikan hambatan listrik yang akan masuk menuju ke LDR agar tegangannya berkurang.

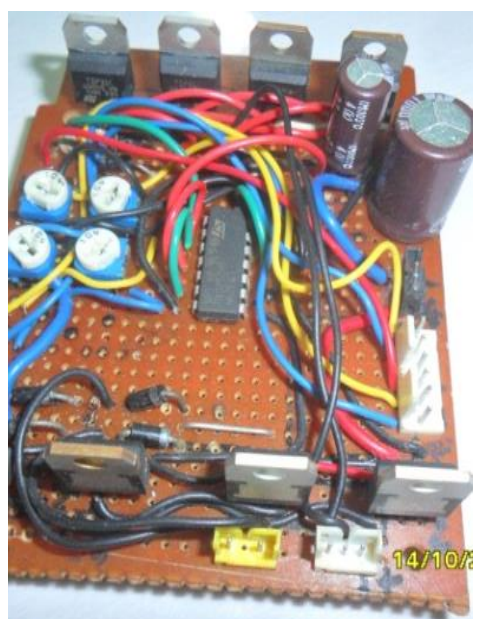

Gambar 6. Controller/ rangkaian electrical

\section{Alat Penelitian}

a. Volt Meter Digunakan untuk mengukur tegangan pada output solar cel maupun input controller.

b. Ampre meter yang digunakan yaitu merek sanwa. Yang berfungsi mengukur arus pada output solar cell jika diberi hambatan.

c. Ohm meter digunakan untuk mengukur resistan pada komponen resistor baik yang tetap, variable maupul LDR.

\section{Prosedur Penelitian}

1. Tahap persiapan.

a. Membuat rangkaian electrical pada program Liveware. Rangkaian electrical seperti ditunjukkan pada gambar 7 


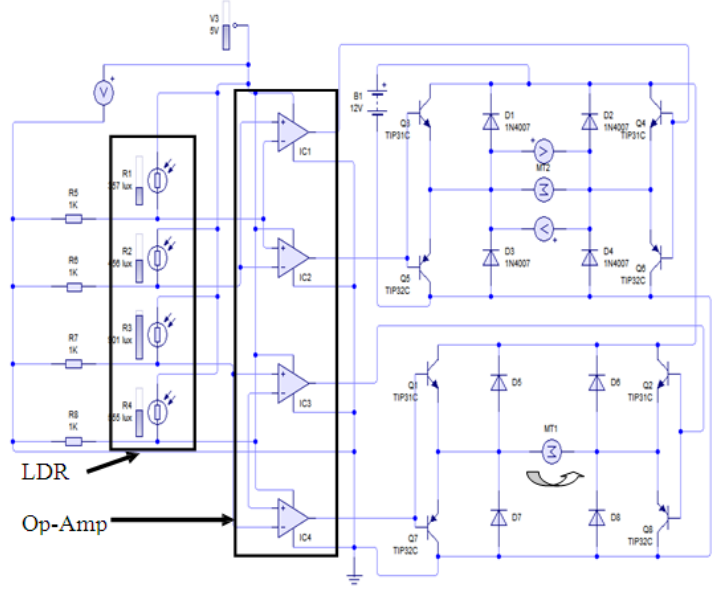

Gambar 7. Rancangan rangkaian elekrical

b. Persiapan dan pemasangan seluruh alat ukur yang digunakan dalam pengujian, seperti: ampremeter, voltmeter dan alat pendukung lainnya.

c. Pengujian rangkaian

d. Warna merah menandakan power (+ batterai) dan Warna hijau menandakan ground (- batterai). Pengujian rangkaian seperti ditunjukkan pada gambar berikut ini

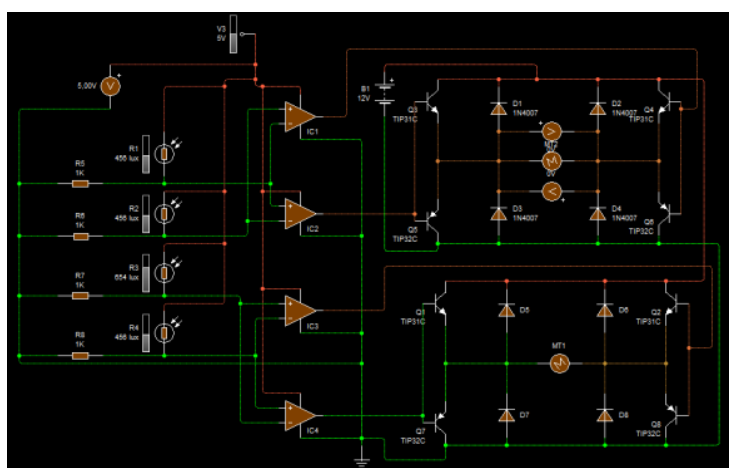

Gambar 8. Pengujian rangkaian electrical

e. Kalibrasi seluruh alat ukur.

2. Tahap pengujian

a. Pasang solar sell dengan sudut $90^{0}$ terhadap permukaan tanah dan pasang solar cell yang telah dilengkapi oleh pencari arah cahaya matahari yang dilengkapi oleh pemfokus cahaya.

b. Lakukan pengukuran tegangan dan arus output solar cell tiap jam mulai pukul 07:00 s/d pukul 17:00 Wita c. Setelah data tegangan dan arus didapatkan maka kita dapat menganalisa untuk dijadikan dalam bentuk grafik dan menghitung charging time solar cell.

\section{Hasil dan Pembahasan}

Pengambilan data dilakukan dengan cara meletakkan solar cell yang telah dilengkapi dengan pemfokus cahaya pada daerah terbuka dan tidak ada bangunan maupun pepohonan yang dapat menyebabkan bayang bayang.

Setelah alat diletakkan pastikan alat tersebut mengarah ke utara atau selatan pada salah satu sisi penggerak serta sisi lainnya pada arah timur atau barat. Setelah alat berada pada posisi yang tepat maka kita dapat memasang sumber arus listrik berupa baterai 12 volt sehingga alat akan bergerak mengarahkan solar sell agar mendapatkan cahaya tegak lurus terhadap titik jatuhnya.

Selain itu terdapat pula solar cell yang tidak dilengkapi dengan pengarah dan pemfokus cahaya agar mengarah tegak lurus $\left(90^{\circ}\right)$ terhadap permukaan tanah dan solar cell mengarah ke matahari.

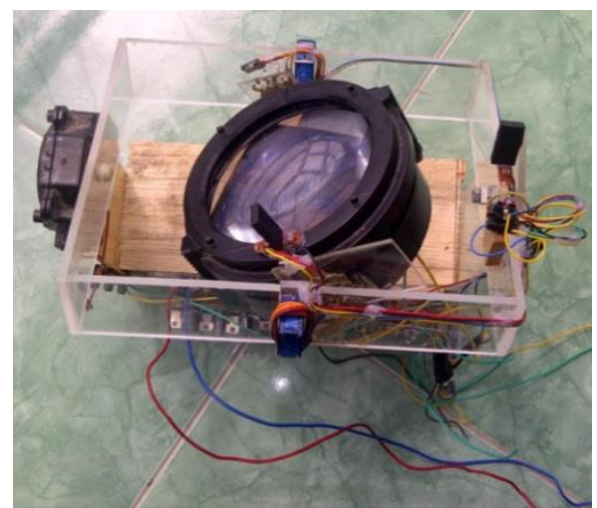

Gambar 9. Prototipe Solar cell yang diteliti 


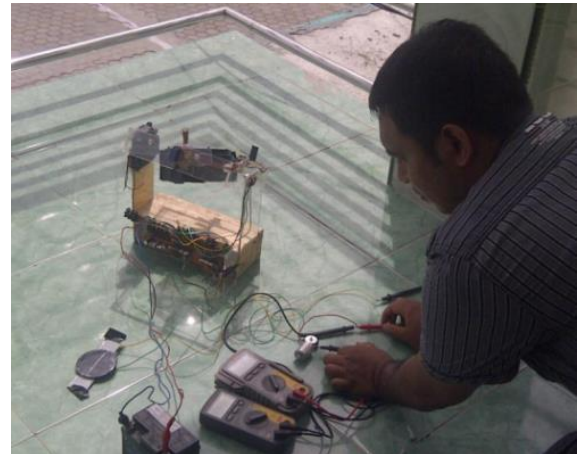

Gambar 10. Pengambilan Data Solar cell

Dari hasil pengukuran tegangan dan arus pada output solar cell tiap jam mulai pukul 07:00 s/d pukul 17:00 Wita. Pada penelitian ini teknik analisa data menggunakan teknik deskriptif berdasarkan hasil penelitian yang dilakukan. Data yang diperoleh dari hasil penelitian kemudian dianalisis menggunakan rumus terapan, Selanjutnya data akan disajikan dalam bentuk grafik dengan bantuan Microsoft Office. Hasil penelitian seperti ditunjukkan pada tabel 1 .

Tabel 1. Data pengujian solar cell

\begin{tabular}{|c|c|c|c|c|}
\hline \multirow{2}{*}{$\begin{array}{c}\text { Waktu } \\
\text { penga } \\
\text { mbilan } \\
\text { data }\end{array}$} & \multicolumn{2}{|c|}{$\begin{array}{c}\text { Tanpa alat } \\
\text { tambahan }\end{array}$} & \multicolumn{2}{c|}{$\begin{array}{c}\text { Dengan alat } \\
\text { tambahan }\end{array}$} \\
\cline { 4 - 5 } 07:00 & 0.005 & 0.008 & 5.490 & 0.037 \\
\hline $08: 00$ & 1.320 & 0.014 & 6.140 & 0.038 \\
\hline $09: 00$ & 4.160 & 0.030 & 6.148 & 0.039 \\
\hline $10: 00$ & 5.600 & 0.037 & 6.210 & 0.040 \\
\hline $11: 00$ & 5.770 & 0.037 & 6.270 & 0.039 \\
\hline $12: 00$ & 5.960 & 0.038 & 6.300 & 0.039 \\
\hline $13: 00$ & 5.930 & 0.038 & 6.350 & 0.039 \\
\hline $14: 00$ & 5.580 & 0.036 & 6.350 & 0.040 \\
\hline $15: 00$ & 5.520 & 0.036 & 6.250 & 0.039 \\
\hline $16: 00$ & 4.200 & 0.033 & 6.230 & 0.039 \\
\hline $17: 00$ & 2.300 & 0.014 & 6.110 & 0.038 \\
\hline
\end{tabular}

Dari data hasil pengujian solar cell pada tabel 1 tersebut kemudian dijadikan grafik tegangan dan arus output solar cell sebagaimana ditunjukkan pada gambar 11 dan 12.

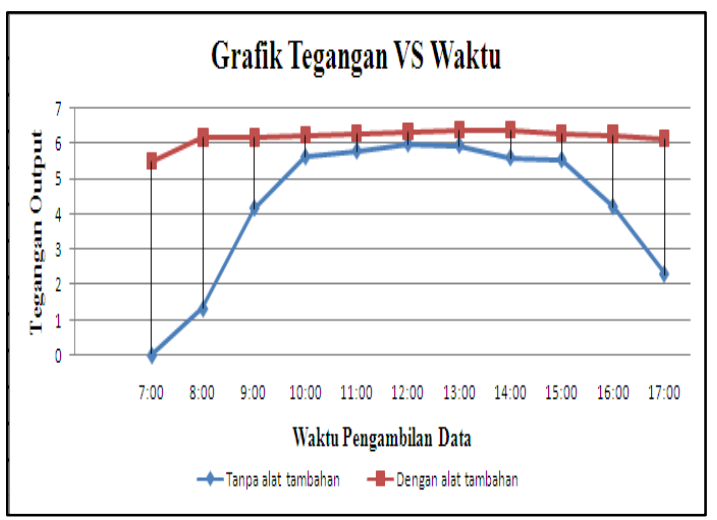

Gambar 11. Tegangan Output solar cell

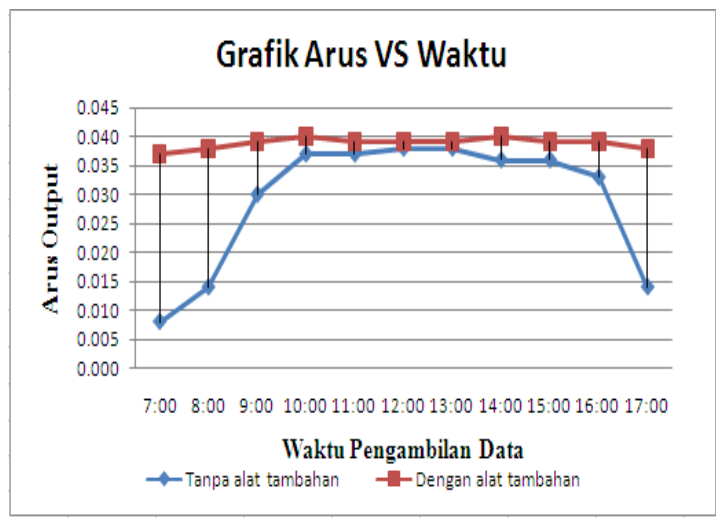

Gambar 12. Arus Output Solar cell

Terjadi penambahan Charging time yaitu mulai pukul 07.00 hingga 17.00 dikarenakan fungsi dari pencari arah sinar matahari yang akan membuat cahaya jatuh tegak lurus terhadap lensa serta pemfokus cahaya yang akan meningkatkan intensitas cahaya yang diterima oleh solar cell. Penambahan waktu charging time didapatkan dari tegangan kerja solar cell pada sistem charging dari senter charge dimana solar cell tersebut diambil yaitu berkisar antara 4 volt.

Apabila charging time solar cell tanpa alat tambahan dimulai dari pukul 09.00 hingga pukul 16.00 (7 jam) sedangkan pada solar cell yang menggunakan alat tambahan, charging time dimulai lebih awal yaitu pada pukul 07.00 hingga pukul 17.00 (10 jam). Dikarenakan solar cell jenis ini menggunakan batterai dengan tegangan 4 volt sehingga charging time 
dimulai apabila tegangan berada di atas tegangan ini, maka penambahan charging time adalah $10 \mathrm{jam}-7 \mathrm{jam}=3 \mathrm{jam}$. Dengan menggunakan rumus presentase maka didapatkan nilai charging time sebesar $(3$ jam : 7 jam $)$ x $100=0,428$ x $100=42.8 \%$.

\section{Kesimpulan}

Alat pencari arah cahaya matahari yang dilengkapi dengan pemfokus cahaya berpengaruh terhadap charging time, pada solar cell yang dilengkapi dengan pencari dan pemfokus cahaya dapat meningkatkan charging time sebesar $42.8 \%$.

\section{Daftar Pustaka}

[1] Anonim, 2005. Photovoltaic Fundamentals.

[2] Ady Iswanto, 2008, Staf Divisi Riset 102FM ITB.

[3] Budhi Priyanto, April 2013, Peningkatan Daya Keluaran Sel Surya Dengan Penambahan Intensitas Berkas Cahaya Matahari, Jurnal Neutrino Vol.5, No. 2, Teknik Elektro Fakultas Teknik Universitas Muhammadiyah Malang.

[4] Budi Yuwono, Februari 2005, Optimalisasi Panel Sel Surya Dengan Menggunakan Sistem Pelacak Berbasis Mikrokontroler At89c51, Universitas Sebelas Maret, Surakarta.

[5] Sumbung, F.H. dan Letsoin, Y, 2012, analisa dan estimasi radiasi konstan energi matahari melalui Variasi sudut panel fotovoltaik shs $50 \mathrm{wp}$ Jurnal Ilmiah Mustek Anim.

[6] Ikhsan, 2013, Peningkatan Suhu Modul Dan Daya Keluaran Panel Surya Dengan Menggunakan Reflektor, Jurnal ilmiah Dosen pada Jurusan Fisika Fakultas Sains dan Teknologi UIN Alauddin Makassar.
[7] Muchammad dan Hendri Setiawan, 2011, Peningkatan Efisiensi Modul Surya $50 \mathrm{Wp}$ Dengan Penambahan Reflektor, Jurusan Teknik Mesin Fakultas Teknik Universitas Diponegoro.

[8] Muhammad. R, 2003, Elektronika Daya, Jilid 1, Prentice Hall Inc., New Jersey.

[9] Mukund R. P, 2000, Wind And Solar Power Sistem, S Merchant Marine Academy Kings, New York.

[10] Supardiono. 2004, lensa dan cermin, Departemen Pendidikan Nasional.

[11] Training Center PT United Tractors Tbk. Electricak System 1 Basic Cours. Jakarta. Juni 2008.

[12] wulandari handini, 2008, performance cel surya, Fakultas Teknik Universitas Indonesia. 